\title{
Measurement of Noise Levels in a Hospital Neonatal Unit in Costa Rica
}

\author{
Juan Carlos Olmo*, Paula Soto Calderon and Carolina Moya Navarro \\ Department of audiologist, Clinicas Audiciòn, San Jose Costa Rica, USA
}

Submission: February 20, 2019; Published: March 11, 2019

*Corresponding author: Juan Carlos Olmo, Department of audiologist, Clinicas Audiciòn, San Jose Costa Rica, USA

\section{Introduction}

The present investigation refers to the issue of the measurement of the noise levels that correspond to the neonatology unit, this is due to the intention to discard or confirm if said unit exceeded the noise levels recommended by the American Academy of Paediatrics (AAP). The effects on hearing of premature babies can be of slow appearance and often go unnoticed. It should be remembered that neonates under $1500 \mathrm{~g}$ will remain in these units for a long time due to their weight and gestational age conditions, which makes them susceptible to further damage. In the preterm neonate there is greater sensitivity to noise, due to physiological immaturity and the vulnerability they have when facing the extra uterine environment, studies have confirmed that the neonate's brain is still immature to record and process all sensory information, which makes them extremely sensitive to noise and other stimuli from the external environment, so that at younger gestational age their sensory and cerebral development is further compromised.

Auditory sensory stimulation can occur from the 32nd week of pregnancy and begins with sounds related to the mother's cardiovascular, respiratory, intestinal and laryngeal activity, so these stimuli are omitted in preterm infants born before this week. Preterm births do not present specific or well-organized auditory responses, unlike a term neonate. Term neonates are at greater risk for certain effects of noise when they present highrisk factors (low birth weight situations, hyperbilirubinemia). The Neonate on the other hand is exposed to stress in the Neonatal unit due to noise, poor tactile stimulation by the parents, for example the lack of caresses that transmit security, or the excessive tactile stimulation by the doctors when performing procedures invasive and not less important stress transmitted from parents to newborns because parents face feelings of pain, fear of loss, anxiety among others.

\section{Justification}

This study aims to know the intensity of existing noise levels and through a professional analysis to raise awareness of whether these levels are harmful or not for the neonates admitted to the neonatal ward. The results of this investigation could be applicable in other areas of health, because the solutions provided can be applicable in any environment of sonic contamination, which threatens the auditory health of other patients of variable ages [1-4].

\section{Background and Definitions}

In Costa Rica, only the research carried out by the audiologist Rodríguez is documented, since 2010 the issue of noise in the neonatology units began to be treated more seriously. Academy of Paediatrics (AAP): dedicates its efforts and resources to the health, safety and well-being of infants, children, adolescents and young adults.

\section{Purpose of the Investigation}

Review the available evidence and answer the question What are the possible factors that cause the high level of noise in a hospital neonatal unit?

\section{Design of the Investigation}

A descriptive research is carried out, making measurements in three different shifts, in two visits made during two days in 2015 performing the calibration prior to taking samples with an acoustic calibrator series 036757 according to the manufacturer's protocol recording the sound level with a S PCE322 A sound level meter, in a Frequency rating on dBA and FAST in a measurement range of $50 \sim 100 \mathrm{~dB}$, is placed on a tripod with a 45 degree angulation in different corridors and units of the Neonatology area, collecting thus the noise made by the staff in their different tasks, changes of shift as well as the noise in general that occurs in the unit [5-8].

\section{Used Materials}

i. Type 2 sound level meter from American National Standard Institute (ANSI). S mark PCEGROUP, model322 A, series 12087542 .

ii. Acoustic Calibrator series 036757, certified number TS12 / 10216. 

iii. Acer branded computer, Intel Atom N570, Windows7.
v. Pencils and pencils.
iv. Tripod brand ALPHA 2500 DESIGN
vi. White leaves.

Analysis of the Results

Table 1: Summary of measurements taken on Friday, February 20, 2015.

\begin{tabular}{|c|c|c|c|c|c|c|c|}
\hline Place Neonatology & Day & $\begin{array}{l}\text { Measurement } \\
\text { in } \mathrm{dB} \text { in the } \\
\text { morning }\end{array}$ & $\begin{array}{c}\text { Surplus } \\
\text { according } \\
\text { to AAP } 45 \\
\text { dB }\end{array}$ & $\begin{array}{l}\text { Measure- } \\
\text { ment in } \\
\text { dB in the } \\
\text { afternoon }\end{array}$ & $\begin{array}{c}\text { Surplus } \\
\text { according } \\
\text { to AAP } 45 \\
\text { dB }\end{array}$ & $\begin{array}{l}\text { Measure- } \\
\text { ment in } \\
\text { dB in the } \\
\text { night }\end{array}$ & $\begin{array}{c}\text { Surplus } \\
\text { according } \\
\text { to AAP } 35 \\
\text { dB }\end{array}$ \\
\hline Enchanted Phototherapy & $\begin{array}{l}\text { Friday } 20 \text { Feb- } \\
\text { ruary }\end{array}$ & $59 \mathrm{~dB}$ & $14 \mathrm{~dB}$ & $50 \mathrm{~dB}$ & $5 \mathrm{~dB}$ & $69 \mathrm{~dB}$ & $34 \mathrm{~dB}$ \\
\hline Inmates intermediate care 2 & $\begin{array}{l}\text { Friday } 20 \text { Feb- } \\
\text { ruary }\end{array}$ & $60 \mathrm{~dB}$ & $15 \mathrm{~dB}$ & $53 \mathrm{~dB}$ & $8 \mathrm{~dB}$ & $69 \mathrm{~dB}$ & $34 \mathrm{~dB}$ \\
\hline Inmates intermediate care 1 & $\begin{array}{l}\text { Friday } 20 \text { Feb- } \\
\text { ruary }\end{array}$ & $49 \mathrm{~dB}$ & $4 \mathrm{~dB}$ & $61 \mathrm{~dB}$ & $16 \mathrm{~dB}$ & $50 \mathrm{~dB}$ & $15 \mathrm{~dB}$ \\
\hline Neo Intensive Care & $\begin{array}{l}\text { Friday } 20 \text { Feb- } \\
\text { ruary }\end{array}$ & $51 \mathrm{~dB}$ & $6 \mathrm{~dB}$ & $59 \mathrm{~dB}$ & $14 \mathrm{~dB}$ & $52 \mathrm{~dB}$ & $17 \mathrm{~dB}$ \\
\hline $\begin{array}{l}\text { Hallway in front of bedridden Photother- } \\
\text { apy }\end{array}$ & $\begin{array}{l}\text { Friday } 20 \text { Feb- } \\
\text { ruary }\end{array}$ & $57 \mathrm{~dB}$ & $12 \mathrm{~dB}$ & $58 \mathrm{~dB}$ & $13 \mathrm{~dB}$ & $68 \mathrm{~dB}$ & $33 \mathrm{~dB}$ \\
\hline $\begin{array}{l}\text { Corridor in front of Bedridden intermedi- } \\
\text { ate care } 2\end{array}$ & $\begin{array}{l}\text { Friday } 20 \text { Feb- } \\
\text { ruary }\end{array}$ & $49 \mathrm{~dB}$ & $4 \mathrm{~dB}$ & $57 \mathrm{~dB}$ & $12 \mathrm{~dB}$ & $51 \mathrm{~dB}$ & $16 \mathrm{~dB}$ \\
\hline $\begin{array}{l}\text { Corridor in front of Bedridden intermedi- } \\
\text { ate care } 1\end{array}$ & $\begin{array}{l}\text { Friday } 20 \text { Feb- } \\
\text { ruary }\end{array}$ & $54 \mathrm{~dB}$ & $9 \mathrm{~dB}$ & $58 \mathrm{~dB}$ & $13 \mathrm{~dB}$ & $52 \mathrm{~dB}$ & $17 \mathrm{~dB}$ \\
\hline Corridor in front of Neo Intensive Care & $\begin{array}{l}\text { Friday } 20 \text { Feb- } \\
\text { ruary }\end{array}$ & $55 \mathrm{~dB}$ & $10 \mathrm{~dB}$ & $50 \mathrm{~dB}$ & $5 \mathrm{~dB}$ & $54 \mathrm{~dB}$ & $19 \mathrm{~dB}$ \\
\hline
\end{tabular}

Note that all measurements exceed the maximum permissible noise levels according to the American Academy of Paediatrics. (1) $45 \mathrm{~dB}$ during the day, and $35 \mathrm{~dB}$ for the night.

Table 2: Summary of measurements taken on Saturday, February 28, 2015.

\begin{tabular}{|c|c|c|c|c|c|c|c|}
\hline Place Neonatology & Day & $\begin{array}{c}\text { Measure- } \\
\text { ment in } \\
\mathbf{d B} \text { in the } \\
\text { morning }\end{array}$ & $\begin{array}{c}\text { Surplus ac- } \\
\text { cording to } \\
\text { AAP 45dB }\end{array}$ & $\begin{array}{c}\text { Measure- } \\
\text { ment in } \\
\mathbf{d B} \text { in the } \\
\text { afternoon }\end{array}$ & $\begin{array}{c}\text { Surplus } \\
\text { according to } \\
\text { AAP 45 dB }\end{array}$ & $\begin{array}{c}\text { Measure- } \\
\text { ment in dB in } \\
\text { the night }\end{array}$ & $\begin{array}{c}\text { Surplus } \\
\text { according to } \\
\text { AAP 35 dB }\end{array}$ \\
\hline Enchanted Phototherapy & $\begin{array}{c}\text { Saturday } 28 \\
\text { February }\end{array}$ & $51 \mathrm{~dB}$ & $6 \mathrm{~dB}$ & $60 \mathrm{~dB}$ & $15 \mathrm{~dB}$ & $50 \mathrm{~dB}$ & $15 \mathrm{~dB}$ \\
\hline Inmates intermediate care 2 & $\begin{array}{c}\text { Saturday } 28 \\
\text { February }\end{array}$ & $59 \mathrm{~dB}$ & $14 \mathrm{~dB}$ & $52 \mathrm{~dB}$ & $7 \mathrm{~dB}$ & $16 \mathrm{~dB}$ \\
\hline Inmates intermediate care 1 & $\begin{array}{c}\text { Saturday } 28 \\
\text { February }\end{array}$ & $49 \mathrm{~dB}$ & $4 \mathrm{~dB}$ & $57 \mathrm{~dB}$ & $12 \mathrm{~dB}$ & $60 \mathrm{~dB}$ & $25 \mathrm{~dB}$ \\
\hline Neo Intensive Care & $\begin{array}{c}\text { Saturday } 28 \\
\text { February }\end{array}$ & $51 \mathrm{~dB}$ & $6 \mathrm{~dB}$ & $59 \mathrm{~dB}$ & $14 \mathrm{~dB}$ & $52 \mathrm{~dB}$ & $17 \mathrm{~dB}$ \\
\hline $\begin{array}{c}\text { Hallway in front of bedridden } \\
\text { Phototherapy }\end{array}$ & $\begin{array}{c}\text { Saturday } 28 \\
\text { February }\end{array}$ & $57 \mathrm{~dB}$ & $12 \mathrm{~dB}$ & $55 \mathrm{~dB}$ & $10 \mathrm{~dB}$ & $50 \mathrm{~dB}$ & $15 \mathrm{~dB}$ \\
\hline $\begin{array}{c}\text { Corridor in front of Bedridden } \\
\text { intermediate care 2 }\end{array}$ & $\begin{array}{c}\text { Saturday } 28 \\
\text { February } \\
\text { febrero }\end{array}$ & $58 \mathrm{~dB}$ & $13 \mathrm{~dB}$ & $71 \mathrm{~dB}$ & $26 \mathrm{~dB}$ & $53 \mathrm{~dB}$ & $18 \mathrm{~dB}$ \\
\hline $\begin{array}{c}\text { Corridor in front of Bedridden } \\
\text { intermediate care 1 }\end{array}$ & $\begin{array}{c}\text { Saturday } 28 \\
\text { February }\end{array}$ & $52 \mathrm{~dB}$ & $7 \mathrm{~dB}$ & $55 \mathrm{~dB}$ & $10 \mathrm{~dB}$ & $58 \mathrm{~dB}$ & $23 \mathrm{~dB}$ \\
\hline $\begin{array}{c}\text { Corridor in front of Neo Intensive } \\
\text { Care }\end{array}$ & $\begin{array}{c}\text { Sábado 28 } \\
\text { febrero }\end{array}$ & $55-60 \mathrm{~dB}$ & $10-15 \mathrm{~dB}$ & $48 \mathrm{~dB}$ & $3 \mathrm{~dB}$ & $59 \mathrm{~dB}$ & $24 \mathrm{~dB}$ \\
\hline
\end{tabular}

Note that all measurements exceed the maximum permissible noise levels according to the American Academy of Paediatrics. (1) $45 \mathrm{~dB}$ during the day, and $35 \mathrm{~dB}$ for the night. In this unit, it should meet an average of $45 \mathrm{~dB}$ allowed during the day, while approximately it was possible to reach up to $69 \mathrm{~dB}$ of noise present in several measurements, recorded from different areas of the research site, such as noise caused by monitors, sinks, telephone noises, staff conversing, poorly maintained equipment, air conditioning, high noise changes during staff shift changes, medical visits and visits from parents.

In the research carried out, it was found that the existing noise levels in the neonatology area of the hospital clearly

exceed the permitted and standardized noise levels mentioned above with surpluses of $4 \mathrm{~dB}$ at $34 \mathrm{~dB}$ on Friday Table 1 and on 


\section{Global Journal of Otolaryngology}

Saturday with surpluses of $3 \mathrm{~dB}$ at $26 \mathrm{~dB}$ Table 2 . Analyzing the results, it is found greater intensity of noise in the afternoon hours and less noise during the morning hours, it was observed that during the shift changes of the nursing staff the noise levels were increased. It is found as maximum peak in the morning hours of $60 \mathrm{~dB}$, in the afternoon of $71 \mathrm{~dB}$, and minimum peak in the morning hours of $49 \mathrm{~dB}$, and in the afternoon of $50 \mathrm{~dB}$, on Friday, it is found for Saturday in the hours of the morning a maximum peak of $59 \mathrm{~dB}$, and in the afternoon $71 \mathrm{~dB}$ and as Table 3: Summary of other measurements made in the neonatology unit of the hospital.

\begin{tabular}{|c|c|}
\hline Place Neonatology & Measurements In dB \\
\hline Nurse talking & $54 \mathrm{~dB}$ \\
\hline Hand washing & 61 a $65 \mathrm{~dB}$ \\
\hline Shift change & 58 a $59 \mathrm{~dB}$ \\
\hline Dreaming Monitor & 52 a $65 \mathrm{~dB}$ \\
\hline Opening Syringe Package & 57 a $64 \mathrm{~dB}$ \\
\hline Respirator sounding & $55 \mathrm{~dB}$ \\
\hline Crying baby & $66 \mathrm{~dB}$ \\
\hline Load cart noise & $56 \mathrm{~dB}$ \\
\hline Sound level meter inside closed incubator & $54 \mathrm{~dB}$ \\
\hline Sound level meter inside open incubator & $55 \mathrm{~dB}$ \\
\hline Phone ringing & $57 \mathrm{~dB}$ \\
\hline Taking Hiccup out of Baby & $62 \mathrm{~dB}$ \\
\hline Air conditioner & $55 \mathrm{~dB}$ \\
\hline Opening Incubator & $54 \mathrm{~dB}$ \\
\hline Moving place incubator & $71 \mathrm{~dB}$ \\
\hline Trash change & $52 \mathrm{~dB}$ \\
\hline
\end{tabular}

Note that all measurements exceed the maximum permissible noise levels according to the American Academy of Paediatrics. (1) $45 \mathrm{~dB}$ during the day, and $35 \mathrm{~dB}$ for the night since this can happen at any time of the day.

\section{Conclusion}

The noise levels found in the neonatal unit are above the levels recommended by the American Paediatric Association ( $45 \mathrm{~dB}$ in the day and $35 \mathrm{~dB}$ in the night). Inform the staff of neonatology area about the effects of noise in neonates hearing problems should be detected as early as possible for a timely intervention, taking advantage of the plasticity of the sensory system under development, before three months of life to prevent any type of delays in the acquisition of language and other problems, this through screening (neonatal auditory screening) and audiological evaluations that may allow timely diagnosis, we cannot know at present about the hearing status of neonates who are in the ICU of the Hospital, so these do not have neonatal hearing screening. Make a noise map showing the areas where there is more noise, where it is possible to see that the neonatology unit exceeds the limits allowed by the AAP. In the investigation, it was determined that the noise levels generated in the area do not exceed eighty decibels, so it is not considered that they can damage children's hearing. Even when the noise levels generated do not have the potential intensity to cause noise-induced loss (they do not exceed eighty decibels), a minimum peak in morning and afternoon hours of $48 \mathrm{~dB}$ at $49 \mathrm{~dB}$ (Tables $1 \& 2$ ). The stress caused to babies by noise can cause damage to their development at the neurological level. In summary according to the research carried out if a noise level higher than the normal standards for a neonatology area was found, which will give the necessary recommendations for the personnel that work and information that some are unaware of (Table 3). 
(C) Commons Attribution 4.0 License

(CC) DY Commons Attribution 4.0 License
Your next submission with Juniper Publishers will reach you the below assets

- Quality Editorial service

- Swift Peer Review

- Reprints availability

- E-prints Service

- Manuscript Podcast for convenient understanding

- Global attainment for your research

- Manuscript accessibility in different formats

( Pdf, E-pub, Full Text, Audio)

- Unceasing customer service

Track the below URL for one-step submission https://juniperpublishers.com/online-submission.php 